\title{
Dal rilievo alla pratica del retrofitting: il 'ridisegno del limite' della città storica di Potenza
}

\author{
Antonio Bixio \\ Giuseppe D’Angiulli
}

Abstract

II patrimonio architettonico e urbano, appartenente alla città moderna del ' 900 , non è solo quello delle periferie anonime e monotone, ma esso è anche protagonista di luoghi appartenenti alla città storica, composta da stratificazioni spesso poco omogenee. La didattica e la ricerca, grazie alle discipline del rilievo e della rappresentazione, è capace di dare lettura e interpretazione di questo tessuto urbano e di ridisegnarlo ricostruendone un'identità appartenente ai luoghi. La città di Potenza, in Basilicata, rappresenta un esempio di stratificazione che ha prodotto, all'interno del tessuto storico, un taglio netto di uno dei monumenti della città: la Torre Guevara. Essa e il suo contesto diventano luogo marginale destinato ad assumere le connotazioni di una periferia, a causa anche della 'cortina di edifici residenziali di bassa qualità che li circondano. Lo studio proposto vuole restituire alla città uno dei simboli dimenticati della comunità, dove il disegno assume un vero ruolo progettuale attraverso il ri-disegno del limite della città storica e degli elementi che la compongono. II retrofitting architettonico degli edifici e il ridisegno dell'area attraverso il progetto del verde urbano assumono il ruolo di elemento di connessione tra le parti.
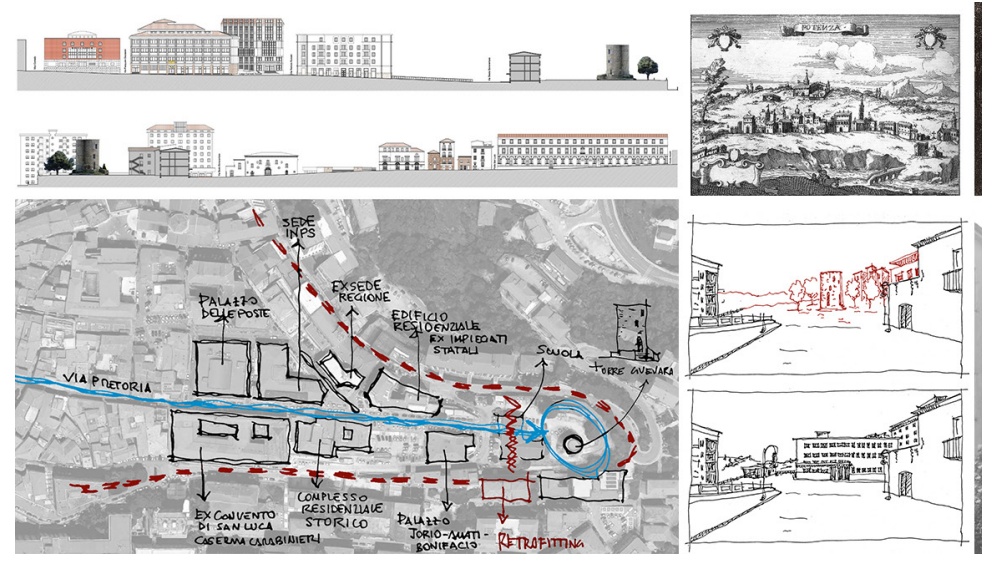
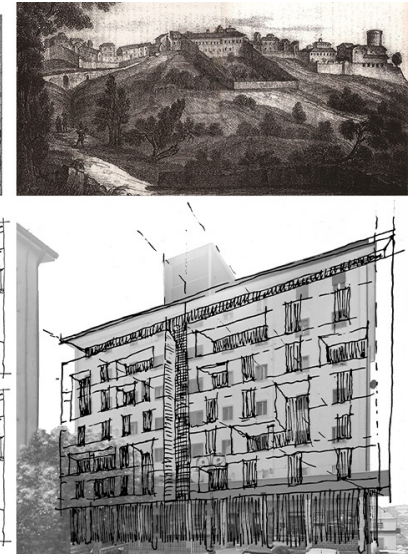


\section{Introduzione}

II Novecento è stato senza dubbio il secolo della modernità, dall'evoluzione della tecnica a quella della comunicazione di massa, le città hanno subito una trasformazione che ha dato vita a insediamenti ed espansioni verso le campagne. Specie negli ultimi decenni, le nuove esigenze e i nuovi standard edilizi e architettonici, assieme alle condizioni socio-economiche, hanno prodotto quello che può essere definito l'humus principale per la costruzione delle periferie urbane e la definizione di tipologie edilizie che hanno contribuito al cambiamento del tessuto urbano. Emergono così, parti di città 'anonime e monotone', insediamenti separati da significative barriere fisiche e sociali capaci di far percepire lo spazio come esterno alla città. Questo sovrastare della 'figura del frammento' della contemporaneità e modernità sulla figura storica della 'continuità' non si avverte solo ai limiti del paesaggio urbano, ma anche in zone appartenenti alla città storica.

Questa realtà, legata a successive stratificazioni spesso rinfuse e poco omogenee, diventa un interessante campo di lavoro dove sperimentare un nuovo approccio alla didattica ed alla ricerca nel campo delle discipline del rilievo e della rappresentazione. Dai processi di conoscenza, tipici del rilievo storico critico, alla lettura ed alla interpretazione del tessuto urbano e dell'architettura, le applicazioni possono lambire anche il tema della progettazione nel termine più appropriato di' 'ridisegno' della città. II disegno, in tal senso, rappresenta una disciplina che, meglio delle altre, può osservare, analizzare e ridisegnare il paesaggio urbano nel tentativo di ricostruirne un'identità storica strettamente legata ad una qualità urbana.

La città di Potenza, oggetto di sperimentazione didattica e di ricerca sui temi sopraccitati, è il classico esempio in cui il limen occidentale della città storica è percepito come un luogo separato da essa, nonostante la forte importanza monumentale documentata dalle numerose presenze storico-architettoniche nel centro storico del capoluogo lucano.

La necessità di ricucire 'esemplari' di edilizia marginale, di bassa qualità architettonica, al tessuto storico diventa occasione di sperimentazione universitaria per proporre soluzioni e modi di agire. Partendo dalle discipline del Rilievo e della Rappresentazione, si definisce la base di un modello operativo per la valorizzazione e la riqualificazione degli 'spazi interstiziali', presenti nei centri storici, dove la reinterpretazione grafica dell'edilizia contemporanea può 'ridisegnare' la qualità urbana spesso perduta. II ridisegno formale e tipologico degli edifici può avvenire attraverso l'atto del retrofitting architettonico, dove la reinterpretazione del linguaggio architettonico originario attraverso l'attualizzazione del progetto sul piano strutturale, tecnologico ed energetico si pone quale strumento per reintegrare e riconnettere più 'sistemi' divisi.

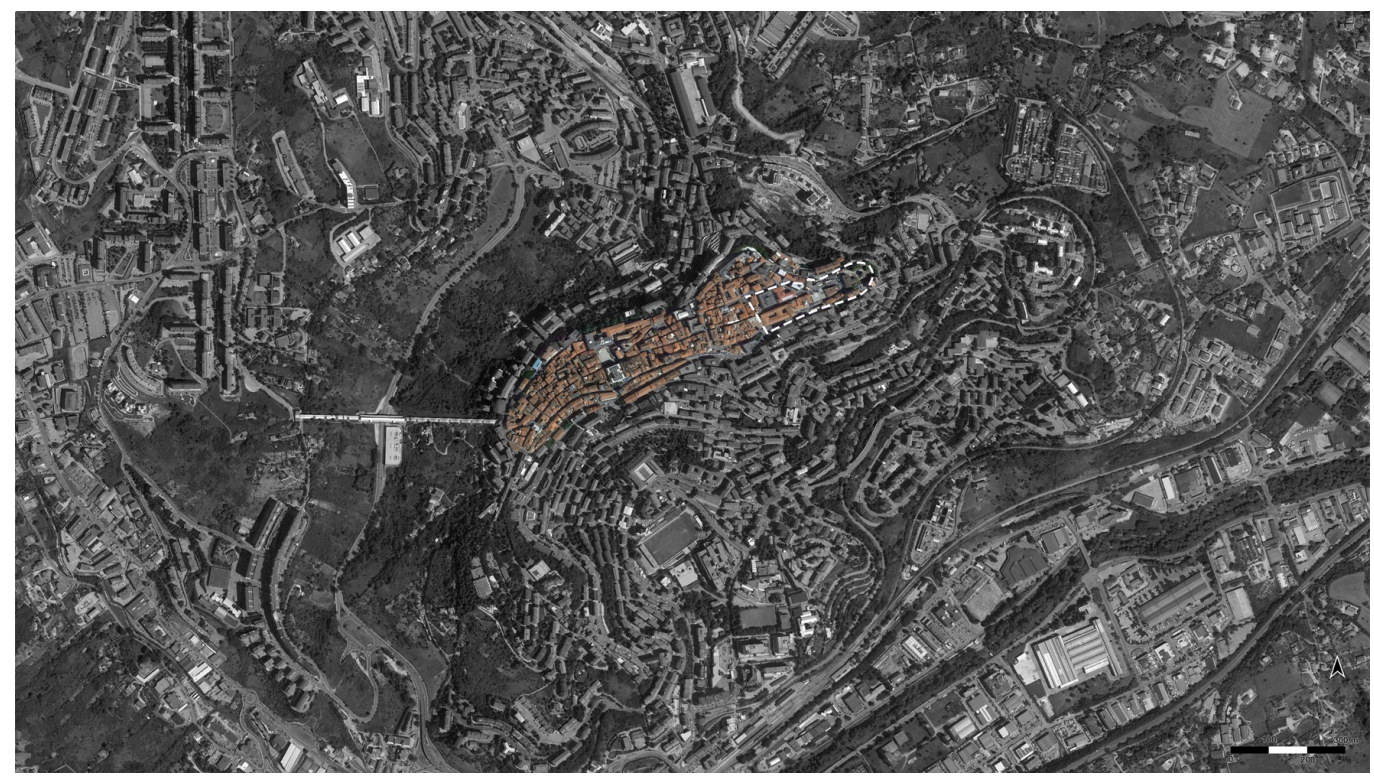




\section{Il castello e via Pretoria: contestualizzazione}

Potenza, capoluogo della regione Basilicata, nota come 'città verticale' per la sua particolare struttura urbanistica a 'terrazzamenti', ha sempre rappresentato un nodo importante tra la Puglia e la Campania. L'area considerata dal 'ri-disegno dell'architettura' è la spina centrale del centro storico della città, via Pretoria, che dal convento di San Luca conduce alla Torre Guevara, unico 'resto' dell'antico castello di Potenza. La zona è l'esito di una serie di interventi di "riqualificazione" del tessuto urbano a partire dagli anni '30 del 1900 coincidente con i primi piani di espansione della città. Accanto ad essi, la politica del 'piccone demolitore' del governo fascista, e lo spirito autarchico del tempo, consolidarono l'immagine dello 'Stato totalitario' attraverso il linguaggio espressivo delle architetture monumentali della Banca d'Italia, la sede del Palazzo INA, progettato da Mario De Renzi, il Palazzo delle Poste dell'architetto Ernesto Bruno La Padula e l'edificio per gli impiegati statali da parte dell'I.N.C.I.S. II palazzo dell'I.N.P.S. e la sede degli uffici della Regione Basilicata realizzati negli anni '60, si relazionano con l'edificio storico del Palazzo Jorio-Amati-Bonifacio e conducono all'edificio scolastico sede dell'I.T.C. Leonardo da Vinci, che nasconde alla vista della Torre Guevara dell'antico castello.

La superstite torre cilindrica di Potenza, sita all'estremità orientale del pianoro su cui è sorto il primo insediamento urbano, probabilmente risale al IX secolo d.C. in concomitanza con la ricostruzione della cinta muraria urbana a seguito del terremoto del 990 d.C. Le dimensioni plano-altimetriche della torre, la sua forma e la sua collocazione fanno pensare ad una struttura costruita con una precisa ed autonoma funzione di vedetta, ma l'assenza di riferimenti ad essa ed al castello nei documenti relativi ai lavori di fortificazione della città tra il XII e il $\mathrm{XV}$ secolo, fa pensare che la munizione non abbia mai rivestito un ruolo significativo nel sistema di difesa della città, considerando il fatto che il sito stesso si presentasse già fortificato per sua natura.

Fig. 2. Elaborazione grafica dell'ipotesi della ricostruzione della pianta del piano terra de Castello e della Torre, dalla fine del XVIII secolo all'inizio del XX secolo, tratte da: Damone 2014, pp. 88-92 Verrastro, Castronuovo 2014].
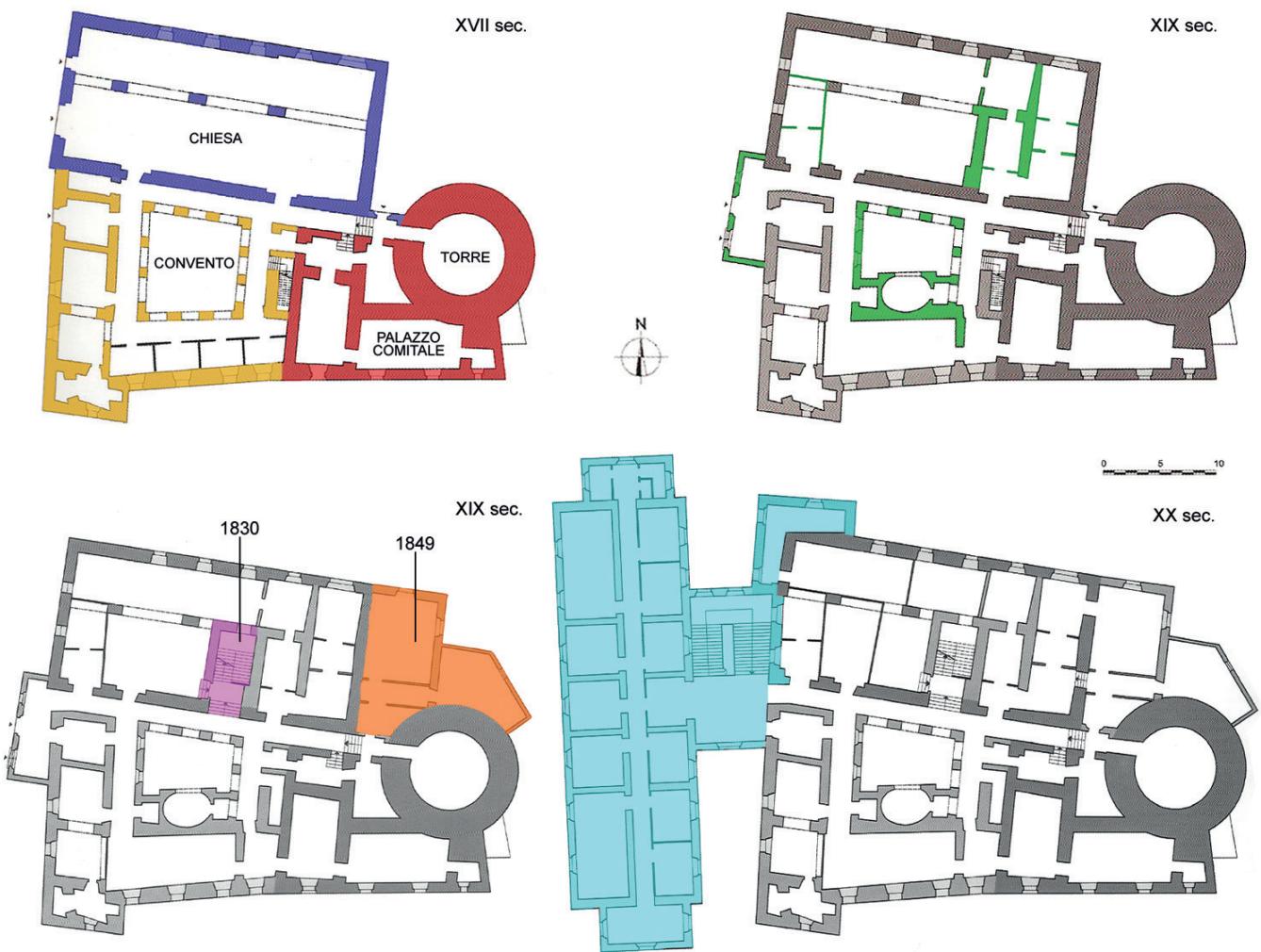
La concessione ai Cappuccini e le mutate caratteristiche da fabbrica militare a conventuale permisero l'uso ospedaliero con ulteriori aggiunte sin dal decennio francese. Dopo il violento terremoto del $\mathbf{8 7 5}$, a causa dei gravi danni alla struttura, furono eseguiti lavori di rifacimento e nei primi anni del $X X$ sec. venne aggiunto un nuovo corpo di fabbrica, sul lato occidentale in adiacenza ai vecchi locali del castello, che consentì una maggiore disponibilità di spazio per gli ambienti di degenza. Durante il ventennio i servizi sanitari vennero spostati in altra sede e a metà del secolo scorso si dispose l'abbattimento della struttura per l'edificazione del plesso scolastico. Tutto ciò che ne rimane è la Torre, oggi sede del Museo del Giardino dell'Agronomo, in memoria di Gioacchino Viggiani. Accanto a questa, dal basso del pianoro si ergono tre edifici di notevole altezza che vanno a circondare il rudere storico, creando quasi una nuova cinta che ostacola lo sguardo verso le valli lucane.

Uno di questi, sede degli uffici dell'Ater di Potenza e destinato ad alloggi, è stato già oggetto di ristrutturazione da parte dello stesso ente ponendo così su questa area un particolare interesse progettuale, specie dal lato accademico. Gli altri due, in attesa di un loro ri-disegno, si mostrano nella loro 'freddezza', testimoni di un progetto speculativo senza mostrare una relazione con il contesto in cui si trovano.

Risulta chiaro quindi come uno degli approcci al recupero di questa area marginale e centrale allo stesso tempo, necessiti l'apertura visiva e fisica verso via Pretoria che ora è impedita dalla struttura anonima della scuola, 'colpevole' della cesura.

Fig. 3. Confronto tra l'Incisione della città di Potenza nel XVIII sec., da: Pacichell 1702; e un disegno della città di Potenza (immagine d'archivio).
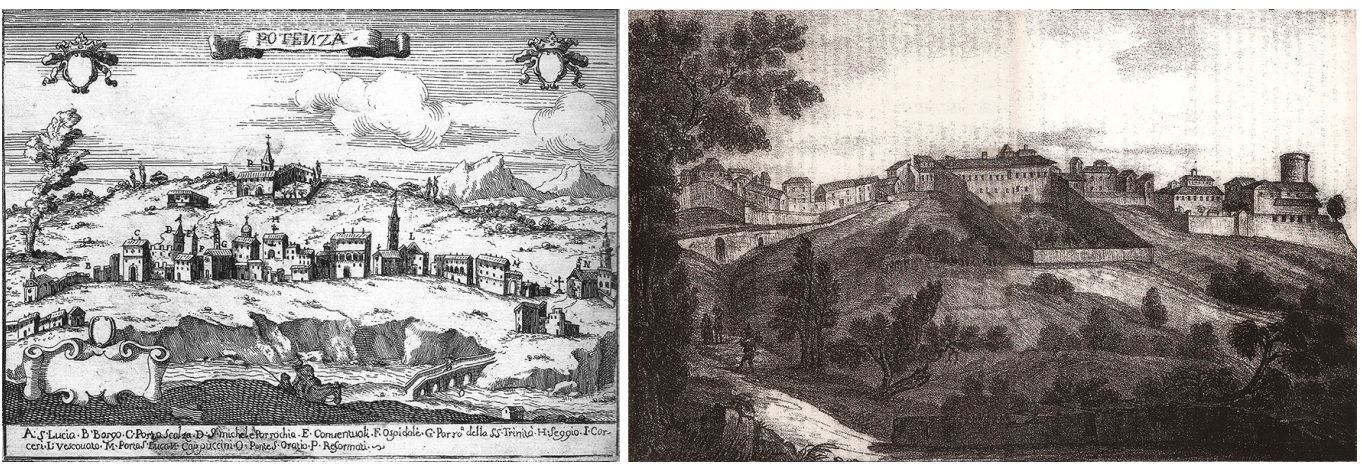

\section{Dal disegno al ri-disegno della città}

La sperimentazione didattica documentata sull'area oggetto di studio, pone le sue basi su un'attenta analisi storico archivistica svolta su tutto il patrimonio edilizio presente sull'asse primario della città storica di Potenza. La fase successiva ha riguardato una schedatura ed il rilievo delle 'emergenze' architettoniche che compongono la scena urbana nelle immediate vicinanze dell'area oggetto di studio.

Infatti, ripercorrendo via Pretoria, asse primario del centro storico di Potenza, fino ad arrivare alla torre Guevara, rilevandone caratteristiche compositive e costruttive, avviene già una prima riconnessione tra i due principali elementi progettuali: la via 'monumentale' e l'elemento storico da riconsiderare nel tessuto del margine della città storica.

Allontanarsi dall'idea di percepire il tessuto di questa porzione della città come composto da singole testimonianze del costruito, corrispondente quasi sempre alle successive stratificazioni storiche, e pensare invece ad un possibile unicum, induce ad affrontare il tema della 'riconnessione', dove elementi fisicamente vicini ma lontani sia nella storia, sia nelle funzioni che nel impatto visivo, sono protagonisti di nuovo disegno della città che può porre le basi al progetto di riqualificazione e di rigenerazione urbana.

Lo studio proposto [ $\mathrm{I}$ ] ha il compito di restituire alla città di Potenza uno dei simboli dimenticati dalla comunità quale monumento autentico: la Torre Guevara. A tale scopo, il ridisegno dei luoghi ha previsto, in primis, la cancellazione dell'edificio scolastico degli anni sessanta, 
Fig. 4. Confronto fotografico tra due immagini del castello (immagini d'archivio).
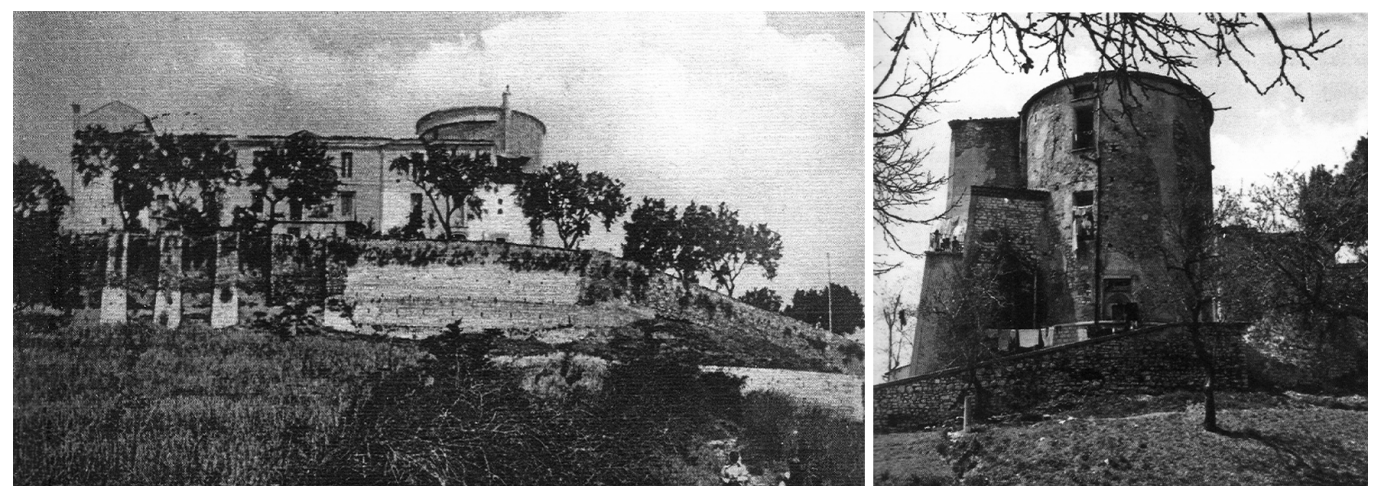

oggi in disuso e senza alcun valore architettonico o storico, che attualmente nega il ruolo di 'terminale' dell'asse stradale pedonale della via Pretoria.

Nell'esperienza di ridisegno dell'area si è data forte importanza alla presenza del verde urbano quale elemento di connessione tra le parti non omogenee che lambiscono la torre. La realizzazione di un Parco Urbano (orto botanico) infatti, da affidare alla gestione dell'Ordine dei Dottori Agronomi e dei Dottori Forestali della Provincia di Potenza, che già si occupa della Torre, si pone come ulteriore collegamento tra la memoria della città e la sua trasformazione con sperimentazioni capaci di arricchire la cultura agricola, di piccola scala, nella città.

Non meno importante dell'impatto ambientale è quello sociale. Infatti, gli orti urbani sono capaci di promuovere l'inclusione sociale e lo sviluppo di nuove comunità: ci si incontra, si condividono esperienze, si sta insieme. Per queste ragioni si propone l'idea di realizzare un Parco Urbano fruibile a 360 gradi, come luogo di sperimentazione agricola, come luogo di conoscenza attraverso attività di educazione ambientale, come luogo ricreativo, capace di accogliere l'intera popolazione, dai bambini agli anziani.

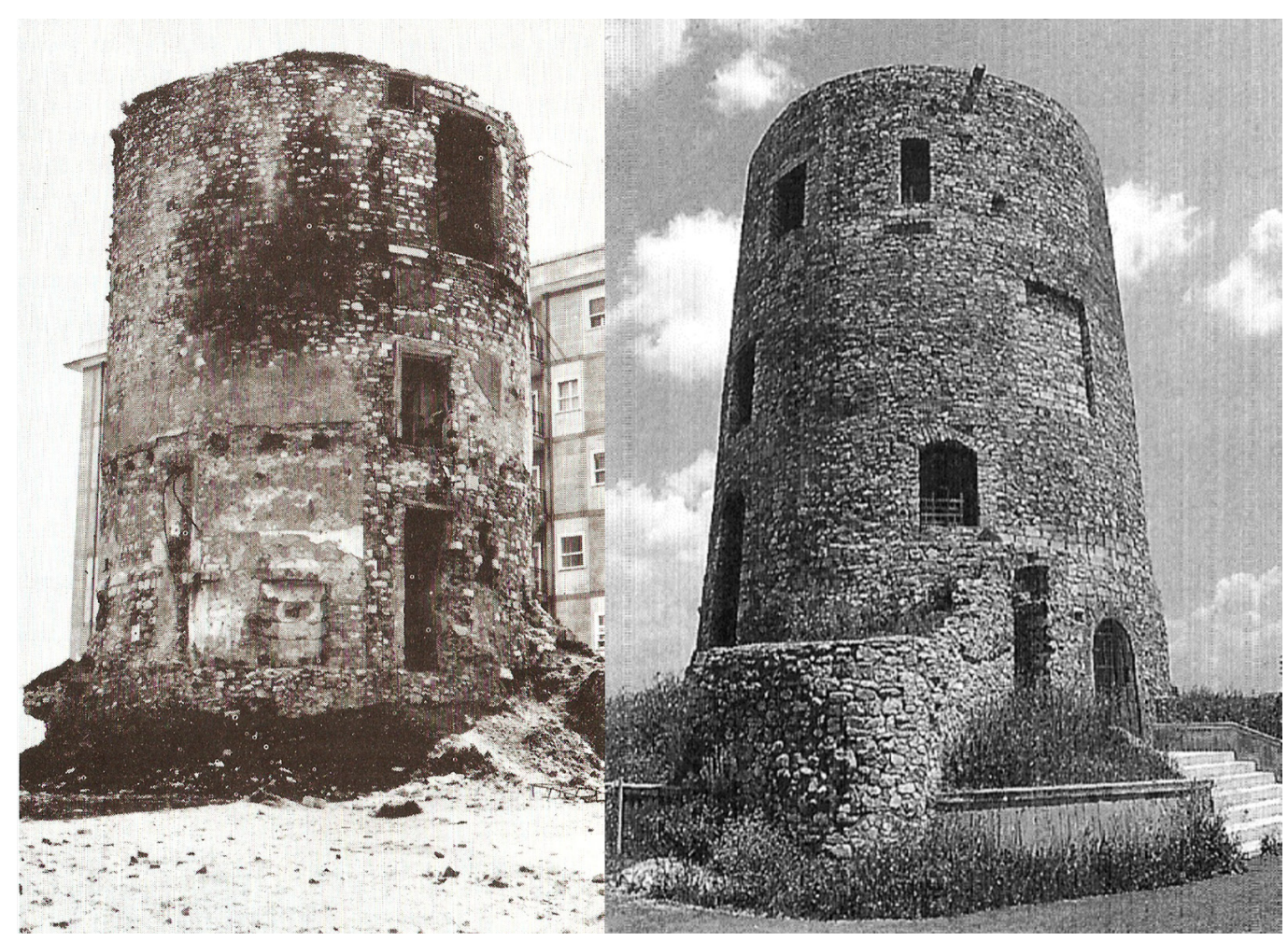

Fig. 5. Confronto fotografico tra la Torre danneggiata dal terremoto del 1980 (sinistra) tratta da: Borghini 1984; e della Torre dopo il restauro (destra) tratta da:

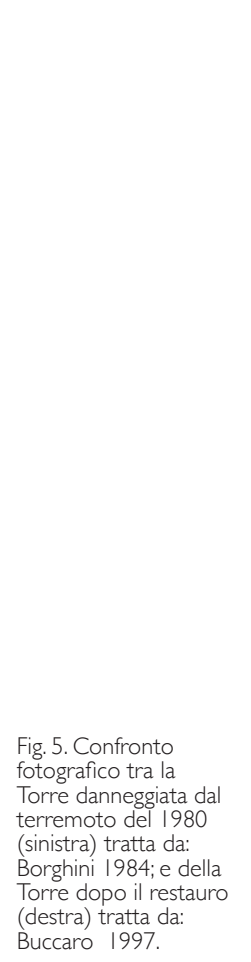


La sperimentazione svolta sull'area di studio si completa con la reinterpretazione grafica del palazzo che si erige a ridosso della torre, collegato tramite un ballatoio al Palazzo degli uffici dell'Ater di Potenza, risalente alla fine degli anni '50. Si pongono, infatti, con lo strumento del disegno tradizionale ed info-grafico, le basi per un progetto di attualizzazione dell'architettura in un'ipotesi di retrofitting architettonico ed urbano. II recupero dell'edificio, qui reinterpretato unicamente nella sua componente 'estetica', porta con sé problematiche legate alle fasi di ingegnerizzazione dell'intervento, ovvero di ammodernamento strutturale e di miglioramento energetico, non trattate in questa sede, che renderebbero attuale il sistema abitativo risalente a diversi decenni fa. Tale approccio al recupero del patrimonio edilizio esistente si pone come alternativa alla demolizione e ricostruzione e diventa, pertanto, l'opportunità per utilizzare fondi attualmente disponibili quali il Sismabonus, l'Ecobonus e il bonus facciate. L'esperienza del retrofitting architettonico quale applicazione di sintesi tra la conoscenza ed il progetto, attraverso il ri-disegno dell'edilizia esistente può innescare un processo virtuoso per il miglioramento della qualità dell'abitare e del vivere la città.

La rigenerazione urbana di un frammento importante della città deve tener conto del suo contesto e degli elementi che lo compongono, percependolo come un essere vivente multicellulare che è capace di metabolizzare le scelte più corrette attivando processi positivi di sostenibilità.

Si può individuare nel retrofit un dispositivo compositivo che è capace di coniugare soluzioni tecniche e tecnologiche con gli aspetti formali e morfologici dell'edificio. Attraverso le operazioni e gli strumenti appartenenti alla materia del disegno e della composizione, quali la sottrazione e l'addizione di volumi e forme, si arriva a definire un progetto che appartiene alla scala urbana.

L'addizione di volumi in facciata, ha permesso un avanzamento dei fronti a filo con il ballatoio sottostante. La ridefinizione delle facciate, con un gioco di volumi e materiali, permette così la realizzazione ad ogni piano di logge/terrazze dalla conformazione flessibile, che offrono
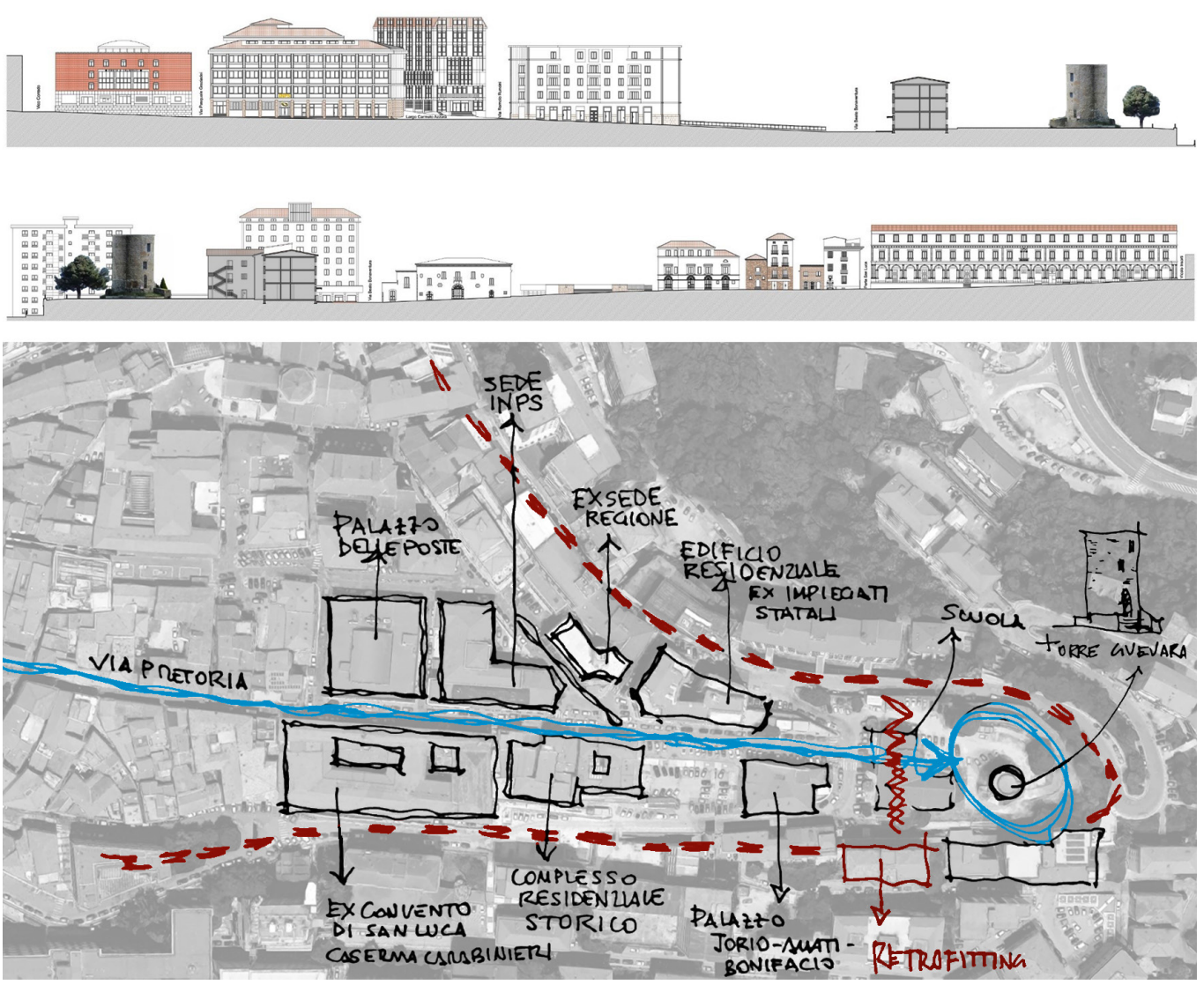

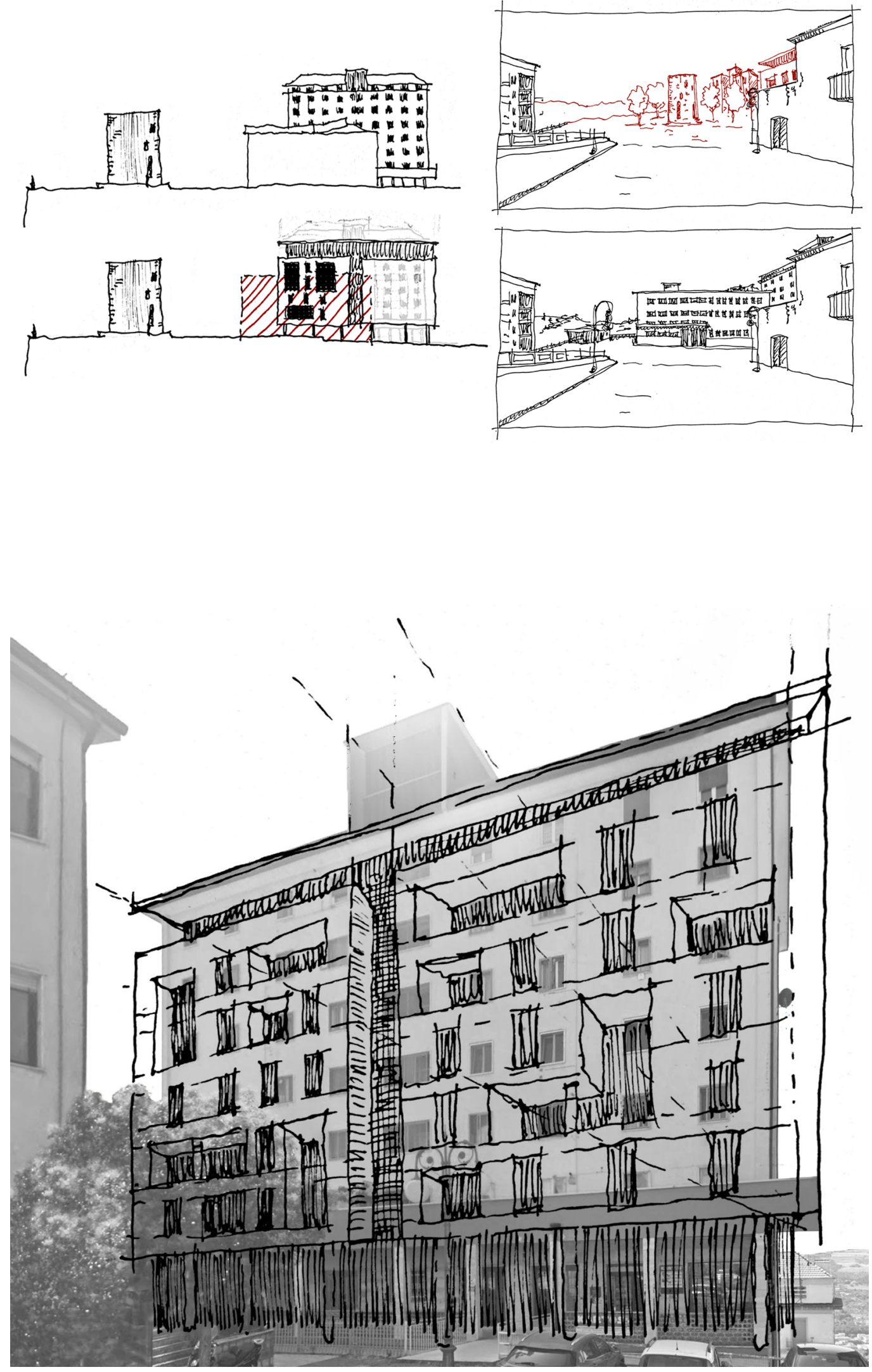
Fig. 9. Elaborazione grafica, render, del Parco Urbano e dell'operazione di retrofitting.

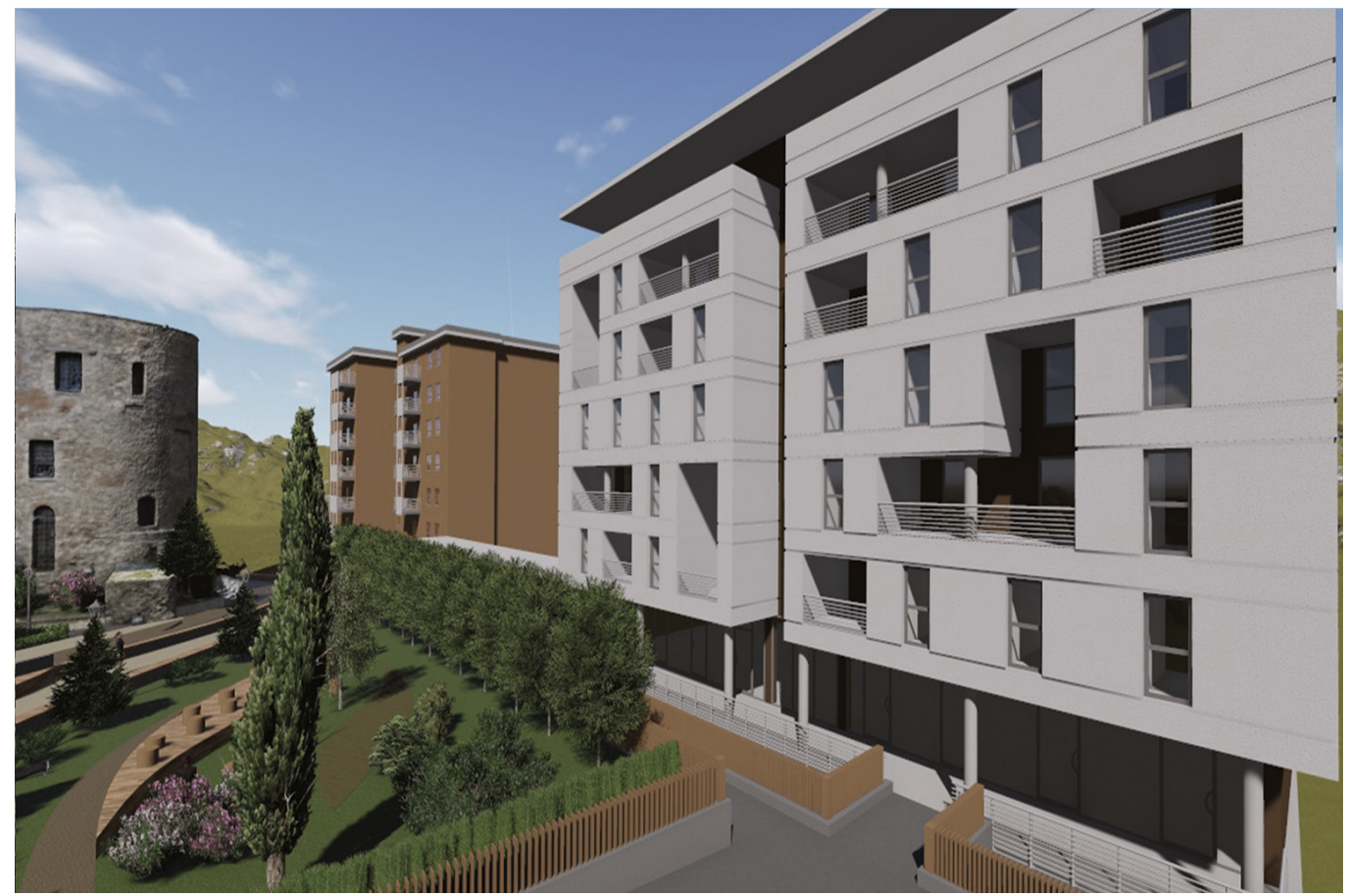

ai residenti la possibilità di migliorare la distribuzione spaziale interna del proprio alloggio e di avere un affaccio sul Parco Urbano della città. Una particolare attenzione è posta nel ridisegnare la copertura: prevedendo un arretramento dell'ultimo piano ed enfatizzando l'elemento di copertura piana in aggetto. II complesso risulta, infatti, ridimensionato nell'altezza ed è capace di dialogare meglio con il Parco e la Torre.

L'edificio assume, in questo modo, un nuovo linguaggio che meglio dialoga con la città storica, in un unicum che si compone di elementi discontinui ma omogeneizzati dalla riconnessione a verde urbano. L'ipotesi di retrofitting adottata restituisce alla città, e a questa porzione di tessuto storico, un edificio con una facies contemporanea che si relaziona in maniera colloquiante con gli altri elementi di progetto.

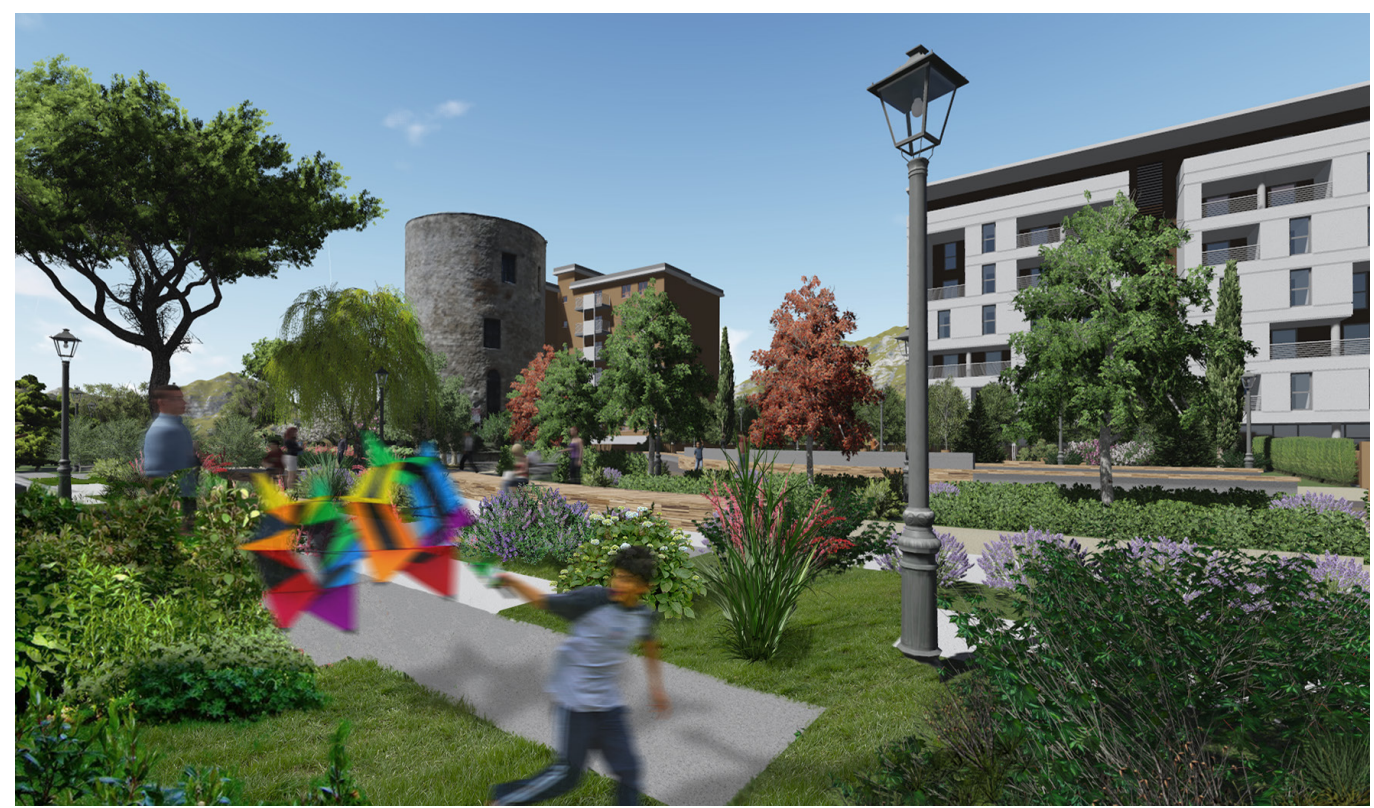


In questo modo la riconnessione non è avvenuta solo sul piano orizzontale (via Pretoria -Torre) ma anche sul piano verticale dove l'altezza della torre dialoga con l'altezza dell'edificato che la circonda che rappresenta le vere mura della città storica.

Lo studio fin qui eseguito, supportato costantemente dal rapporto biunivoco tra la disciplina del Rilievo e quella del Disegno è riuscito a concretizzare anche se idealmente l'obiettivo primario: dar nuova luce, identità e dignità e qualità urbana all'area della Torre Guevara di Potenza.

\section{Note}

[I] II presente studio è stato in parte oggetto della Tesi di Laurea in Ingegneria Edile-Architettura, Scuola di Ingegneria dell'Università degli Studi della Basilicata, discussa dalla Dott.ssa Daniela Sabato dal titolo Dal rilievo alla riqualificazione dei centri storici. Il Parco Urbano della Torre Guevara a Potenza, A.A. 20 I8-2019; relatore prof. ing. Antonio Bixio.

\section{Riferimenti bibliografici}

Ascione Paola, Bellomo Mariangela (2012). Retrofit per la residenza. Tecnologie per la riqualificazione del patrimonio edilizio in Campania. Napoli: Clean Edizioni.

ATER POTENZA (2006). L'esperienza dell'abitare: progetti e realizzazioni in provincia di Potenza. Melfi: Libria.

Bixio Antonio, Tolla Enza (2012). Un Laboratorio per il Rilievo. Salerno: CUES.

Bixio Antonio, Tolla Enza, Damone Giuseppe (20I5). Besides the Design: the Analysis and Documentation of the Ancient "Via Pretoria" in Potenza. The Most Significant Transformations of a Roman Road Axis in the Historic City. In Carmine Gambardella (a cura di). Heritage and Technology. Mind Knowledge Experience. Napoli: La Scuola di Pitagora, pp. 97- 05.

Borghini Andrea (1984). Potenza perché ... Potenza: Ente Provinciale per il Turismo.

Buccaro Alfredo (1997). Le città nella storia d'Italia Potenza. Bari: Laterza.

Damone Giuseppe (2014). Studio dell'evoluzione architettonica del San Carlo tra iconografia e storiografia. In Verrastro Valeria, Castronuovo Angela (a cura di). Per ben servire l'umanità languente. Lagonegro: Zaccaria Editore, pp. 88-92.

De Nucci Alberto, Tolla Enza (1988). Via Pretoria - Didattica della rappresentazione per la rilettura della città. Potenza:Tipografia Zafarone e Di Bello.

Giambaresio Valerio ( 1995). Guida all'Architettura del novecento a Potenza. Melfi: Libria.

Gregotti Vittorio (20|4). Il possibile necessario. Milano: Bompiani.

Luccioni Luigi (1983). Un Saluto da Potenza. Ercolano: La Buona Stampa.

Murgante Beniamino (2005). Le vicende urbanistiche di Potenza. Potenza: Editric Ermes.

Pacichelli Giovanni Battista ( 1702). Il regno di Napoli in prospettiva: diviso in dodeci provincie. Napoli: D.A.Parrino.

Ricciuti Michele Davide (2009). Sulle condizioni igieniche della città di Potenza: una proposta programmatica sanitaria di fine Ottocento. Lavello: Calice.

Russo Ermoli Sergio, D'Ambrosio Valeria (2012). The building retrofit challenge - Programmazione, progettazione e gestione degli interventi in Europa. Firenze: Alinea Editrice.

Secchi Bernardo (2007). Prima lezione di urbanistica. Bari: Laterza.

Sannino Anna Lisa (1990). Territorio e popolazione a Potenza nell'età moderna. Roma: Edizioni di storia e letteratura.

Verrastro Valeria, Castronuovo Angela (20 I4). Per ben servire l'umanità languente. Lagonegro: Zaccaria Editore.

\section{Autori}

Antonio Bixio, Università degli Studi della Basilicata, antonio.bixio@unibas.it

Giuseppe D’Angiulli, Università degli Studi della Basilicata, giuseppe.dangiulli@unibas.it

Per citare questo capitolo: Bixio Antonio, D'Angiulli Giuseooe (2020). Dal rilievo alla pratica del retrofitting: il 'ridisegno del limite' della città storica di Potenza/From surveying to the retrofitting: the 'redesign of the limit' in the historical city of Potenza. In Arena A., Arena M., Brandolino R.G. Colistra D., Ginex G., Mediati D., Nucifora S., Raffa P. (a cura di). Connettere. Un disegno per annodare e tessere. Atti del $42^{\circ}$ Convegno Internazionale dei Docenti delle Discipline della Rappresentazione/Connecting. Drawing for weaving relationships. Proceedings of the 42th International Conference of Representation Disciplines Teachers. Milano: FrancoAngeli, pp. $915-932$. 


\title{
From Surveying to the Retrofitting: the 'Redesign of the Limit' in the Historical City of Potenza
}

\author{
Antonio Bixio \\ Giuseppe D’Angiulli
}

\section{Abstract}

The architectural and urban heritage of the modern city of' ' 900 , is not only that of the suburbs anonymous and monotonous. It is the protagonist of places belonging to the historical city, composed of uneven stratifications. The didactics and research, thanks to the disciplines of relief and representation, is able to give reading and interpretation of this urban fabric and to redesign it by reconstructing an identity belonging to the places. The city of Potenza, in Basilicata, is an example of the historical fabric interrupted by a cut whit the monument of Guevara Tower. The Tower and its context take on the connotations of a suburb because of the 'curtain' formed by low-quality residential buildings. The proposed study aims to restore to the city one of the forgotten symbols of the community, where the drawing assumes a design role through the re-design of the limit of the historical city. The architectural retrofitting and the redesign of the area with an urban green project create a connection element between the parts.
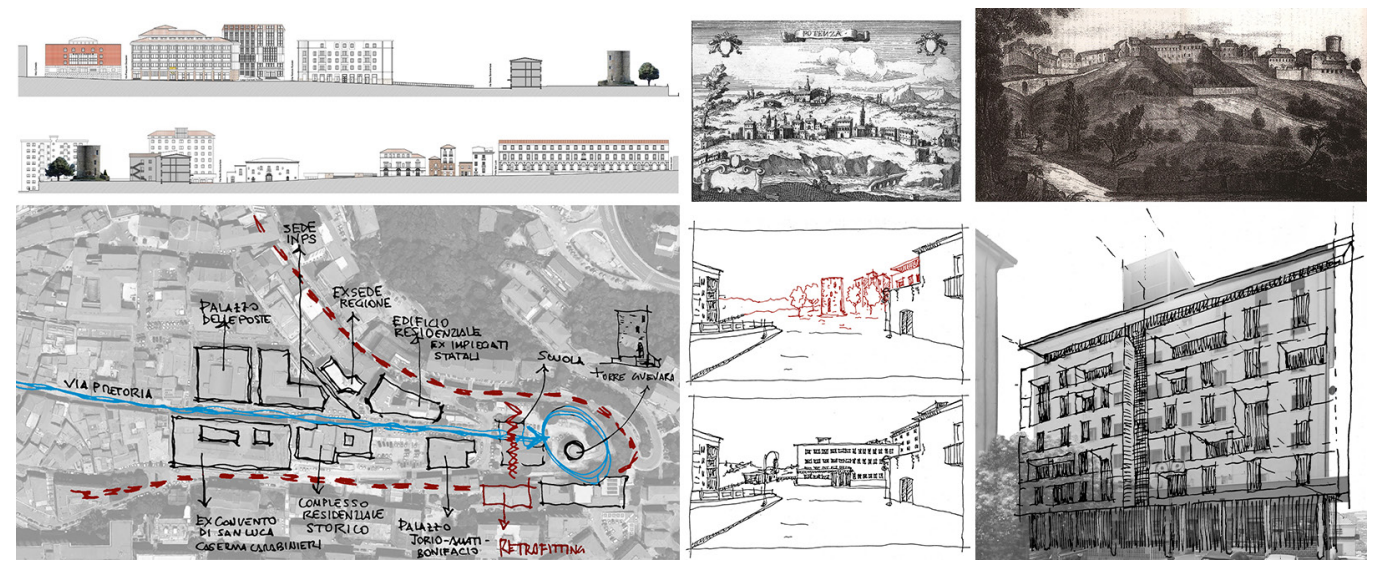


\section{Introduction}

The twentieth century was the century of modernity, from the evolution of technology to mass communication. Cities have been transformed into settlements and expansions into the countryside. Especially in recent decades, new needs, new building and architectural standards, with socio-economic conditions have produced the 'humus' for the construction of urban suburbs, these have also defined building types that have contributed to the change in the urban fabric. There are parts of anonymous and monotonous cities and settlements separated by significant physical and social barriers able to perceive space as external to the city. This overhanging of the 'figure fragment' of contemporaneity and modernity on the historical figure of 'continuity' is felt not only at the limits of the urban landscape, but also in areas belonging to the historical city.

This reality becomes an interesting field of work where to experiment a new approach to teaching and research in the field of the disciplines of survey and representation thanks to the stratifications of the city. From the processes of knowledge of the critical historical survey, to the reading and interpretation of the urban fabric and architecture, the applications can also touch the theme of the design that can be called 'redesign' of the city. Drawing, in this sense, represents a discipline that, better than the others, can observe, analyze and redesign the urban landscape in an attempt to reconstruct a historical identity linked to an urban quality.

The city of Potenza is the subject of didactic experiments and research and represents the classic example where the limit of the old city is perceived as a separate place from the rest of the city, despite the monumental importance documented by the numerous historical-architectural presences in the historical center of Potenza.

The need to connect building with low architectural quality to the historical fabric become an opportunity for university experimentation to propose solutions and ways to acting. Starting from the discipline of survey and representation, we define the basis of an operational model to the valorization and recovery of 'interstitial spaces' in the historical centers. In this method the graphic reinterpretation of the contemporary building can 'redesign' the lost urban quality.

The formal and typological redesign of the buildings can take place through the act of architectural retrofitting, where the reinterpretation of the original architectural language became an opportunity to reintegrate and reconnect 'divided system', thanks to actualization of the project on the structural technological and energy level.

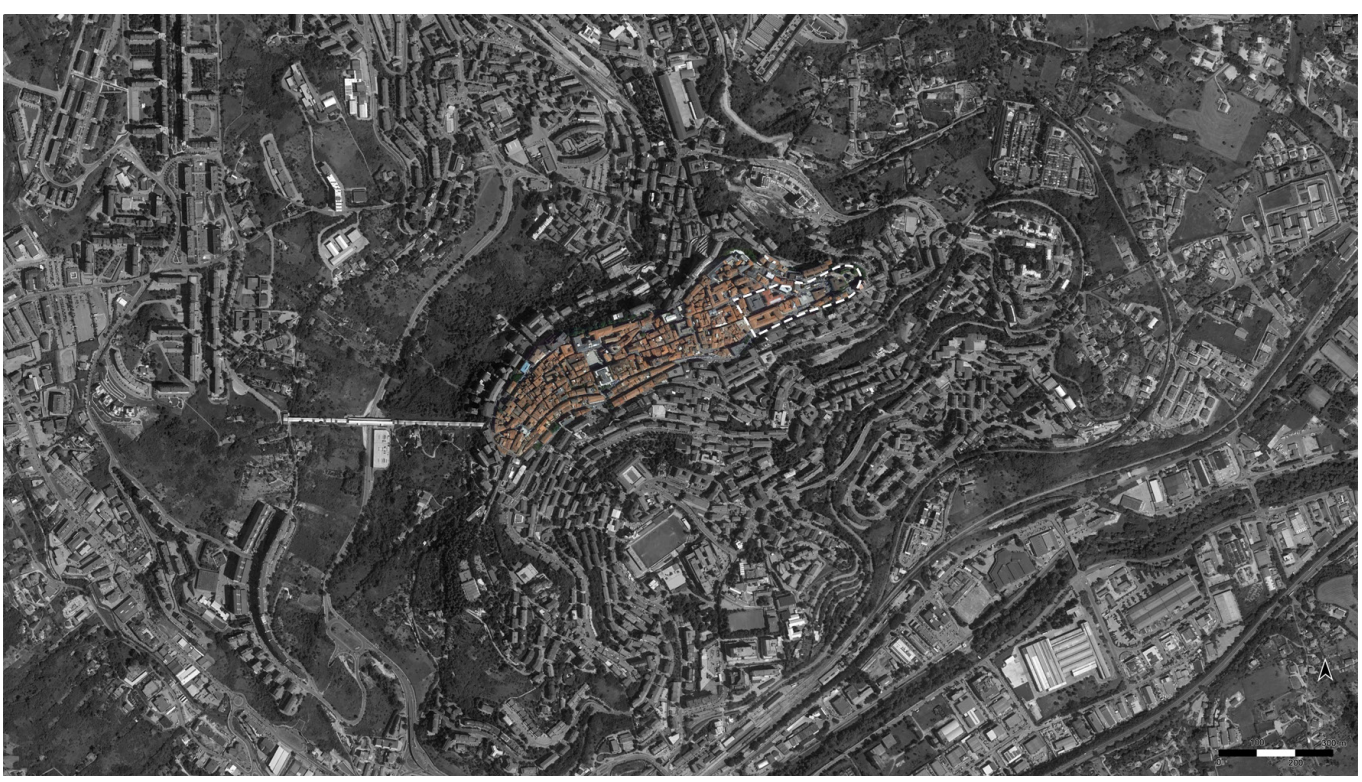




\section{The castle and Pretoria Street: context}

Potenza, capital of the region of Basilicata, known as 'vertical city', has always represented an important junction between Apulia and Campania due to its particular urban structure. The area considered by the 're-design of the architecture' is the central spine of the historical center of the city, Pretoria Street: from the convent of San Luca to the Guevara Tower, the only 'rest' of the ancient castle of Potenza. The area is the result of a series of interventions to redevelop the urban fabric starting from the 30 years of the '900 coinciding with the first plans of expansion of the city. The policy of the 'pickaxe demolition' of the fascist government and the autarchic spirit consolidated the image of the 'totalitarian State' through the expressive language of the monumental architectures of the Banca d'Italia, the seat of Palazzo INA designed by Mario De Renzi, the Palazzo delle Poste of the architect Ernesto Bruno La Padula and the building for civil servants by the I.N.C.I.S.The palace of the I.N.P.S. and the headquarters of the offices of the Basilicata Region, built in the years '60, relate to the historic building of the Jorio-Amati-Bonifacio Palace and lead to the school building of the I.T.C. 'Leonardo da Vinci', which hides from the view of the Guevara Tower of the ancient castle. The surviving cylindrical tower of Potenza is located at the eastern end of the place where the first urban settlement arose, probably dates back to the 9th century A.D. in conjunction with the reconstruction of the city walls following the earthquake of 990 A.D.The plano-altimetric dimensions of the tower, its shape and its location suggest a structure built with a precise and autonomous function of lookout, but the absence of references to it and in the documents relating to the fortification works of the city between the XII and the XV century suggests that the ammunition has never played a significant role in the city's defense system, considering that the site itself was fortified by its nature.

Fig. 2. Graphic elaboration, hypothesis of the reconstruction of the ground floor plan of the Castle and the Tower, from the end of the XVIII century to the beginning of the $X X$ century from: Damone 2014,pp. 88-92 Verrastro Castronuovo 2014].
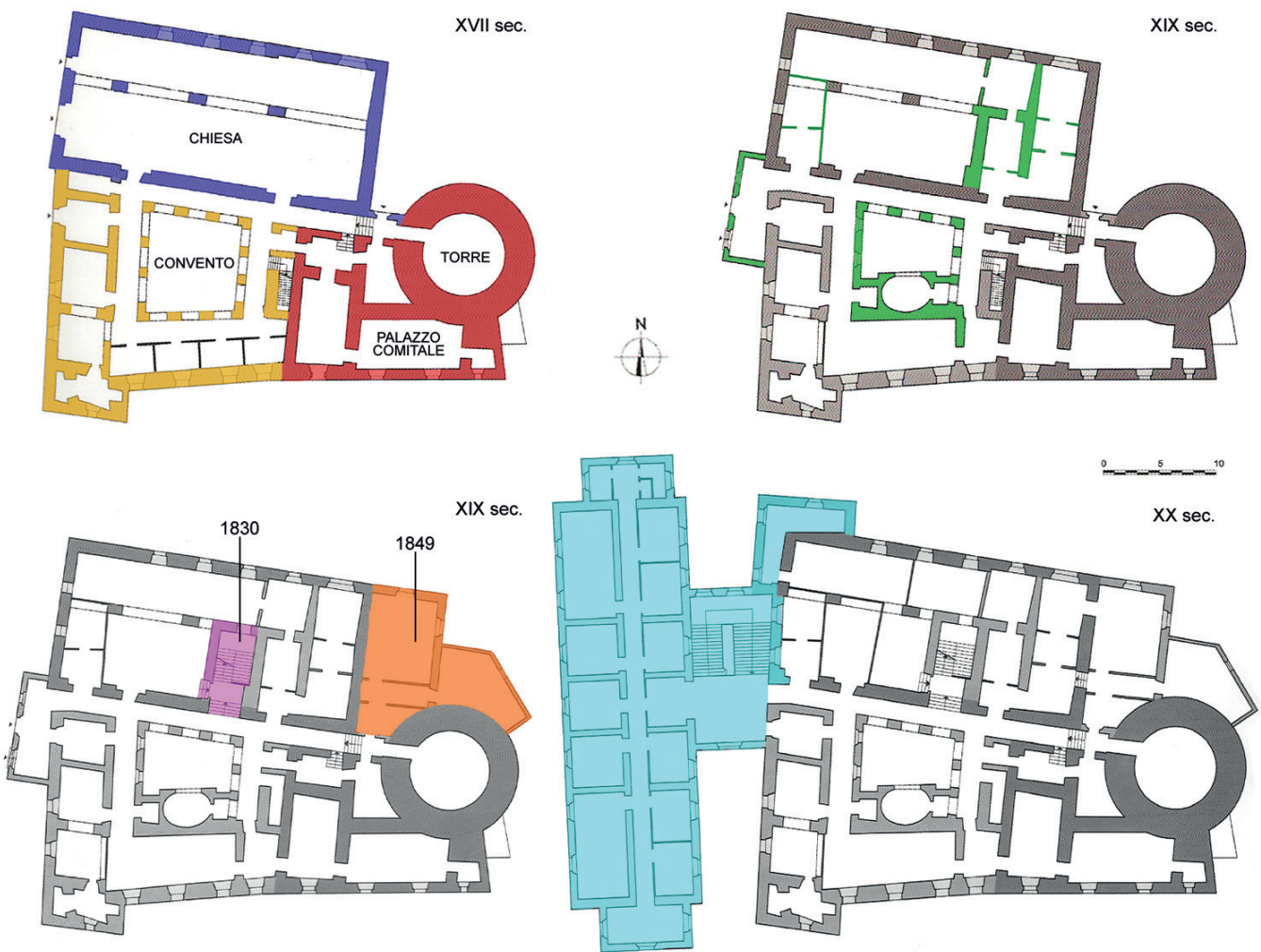
Fig. 3. Comparison tra I'Incisione della città di Potenza nel XVIIIsec. da. Pacichelli 1702: and da. Pacichelli 1702 , and a drawing of Potenza (archive images)
The concession to the Capuchins and the changed characteristics from military factory to conventual allowed hospital use with additions since the French decade. After the violent earthquake of 1875 , because of the serious damage to the structure, were carried out renovations and in the early years of the twentieth century was added a new body of the building on the western side near to the old premises of the castle; this allowed for a greater availability of space for in-patient environments. During the years of fascism government, the sanitary services were moved to another place and in the middle of the last century the demolition of the structure for the construction of the school complex was arranged. The only remaining part of the castle is the Tower, now Museum of the Garden of the agronomist, in memory of Gioacchino Viggiani. Next to it, from the lower part below the plain of the historical city rise three buildings of considerable height that surround the ruin of the castle, creating a new wall that hinders the look towards the valleys of Lucania.

One of these, the headquarters of ATER's offices of Potenza and intended for housing, has already been the subject of renovation by the same agency. This placed on this area a particular design interest, especially on the academic side. The other two are waiting for their re-design and proving to be projects that have no relation to the context in which they are located.

It is clear that one of the approaches to the recovery of this marginal and central area at the same time, necessitates the visual and physical opening towards via Pretoria which is now prevented by the anonymous structure of the school.
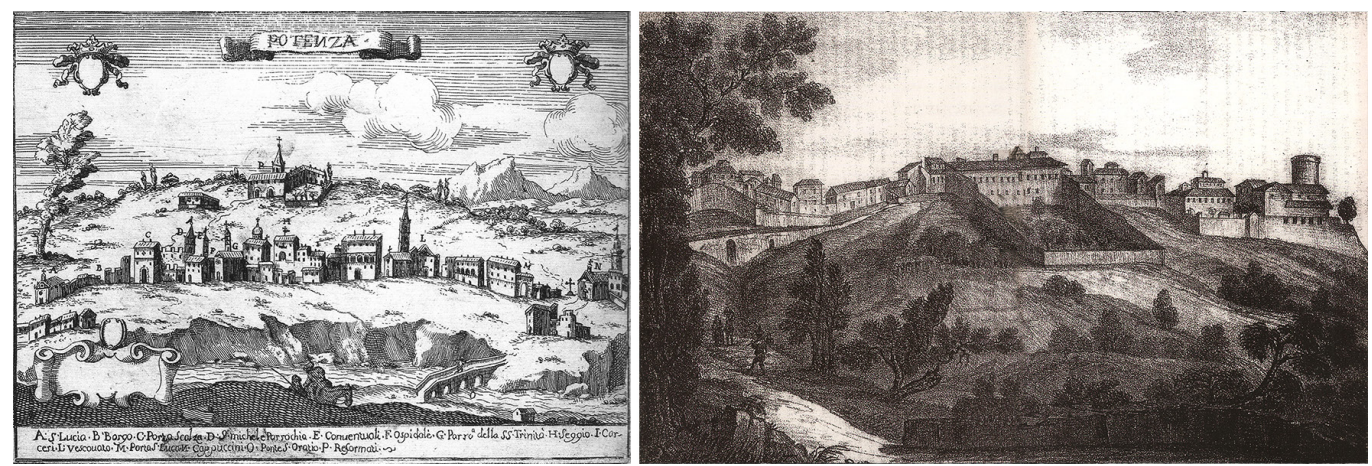

\section{From drawing to redesing of city}

The didactic experimentation on the area studied, begins with a careful historical and archival analysis on all the building heritage present on the primary axis of the historical city of Potenza. The next phase involved a registration and survey of the 'architectural emergencies' that make up the urban scene in the immediate vicinity of the area.

Going along via Pretoria, the main axis of the historical center of Potenza, up to Guevara Tower, the compositive and constructive characteristics are surved and a first reconnection between the two main design elements takes place: the 'monumental Street' and the historical element to be reconsidered in the fabric of the limit of the old city.

The fabric of this part of the city must be perceived as a unicum and not as composed of individual building examples that correspond to the different historical stratifications. This identify the theme of reconnection where elements near physically, but distant on the historical level, and different on the aspect, become protagonists of a new design of the city for the urban redevelopment project.

The proposed studyl has the task of restoring to the city of Potenza one of the symbols forgotten by the community: Guevara Tower. To do this, the redesign of the places considers the elimination of the school building of the sixties, now in disuse and without any architectural or historical value, which currently denies the role of 'terminal' of the street pedestrian axis of the Pretoria Street. 

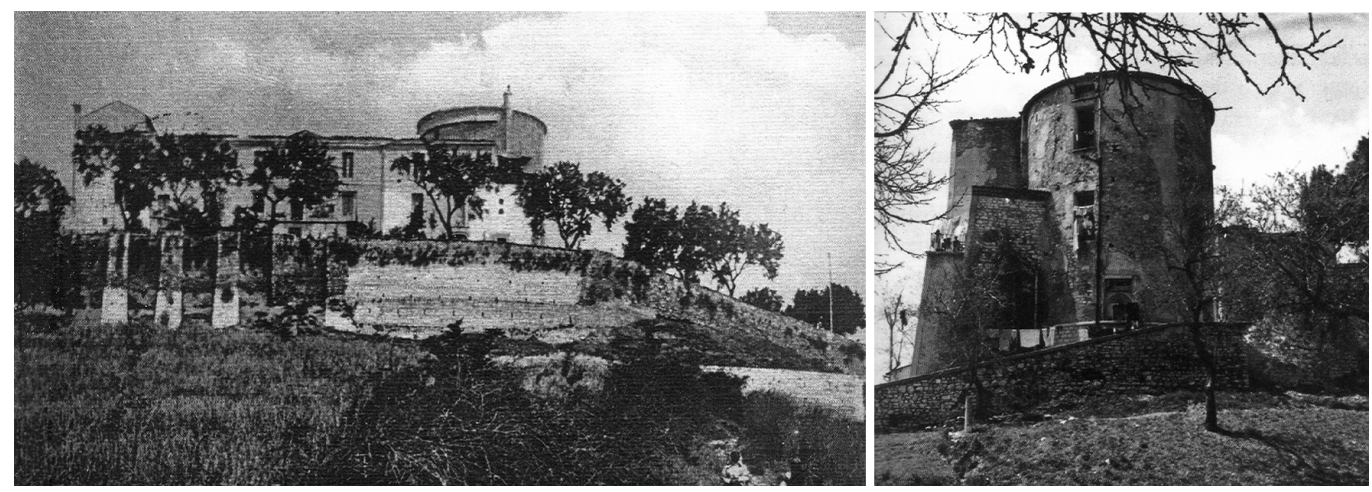

Very important in the experience of redesigning the area was the presence of 'urban green' that became an element of connection between the non-homogeneous parts that lapped the tower.

The realization of an Urban Park (botanical garden) is a further link between the memory of the city and its transformation with experiments capable of enriching the small-scale agricultural culture of the city, thanks to the management of the agronomists and forestry Doctors of the Province of Potenza, which already takes care of the Tower.

The social impact is also important. In fact, urban gardens are able to promote social inclusion and the development of new communities. For these reasons we propose the idea of creating an Urban Park accessible to all citizens, as a place of agricultural experimentation, as a place of knowledge through environmental education activities, as a recreational place, able to accommodate the entire population, from children to the elderly.

The experimentation on the study area is completed with the formal reinterpretation of the building that stands behind the tower, connected through a gallery to the The ATER office building in Potenza (dating back to the late 1950s). With the tool of traditional drawing and info-graphic the bases for a plan of actualization of the architecture in a hypothesis of architectural and urban retrofitting are constructed. In this case, the recovery of the building has

Fig. 5. Photo comparison between the Guevara Tower damaged by the earthquake of 1980 (left) from: Borghini 1984; and the Tower after the restoration (right), from: Buccaro 1997.

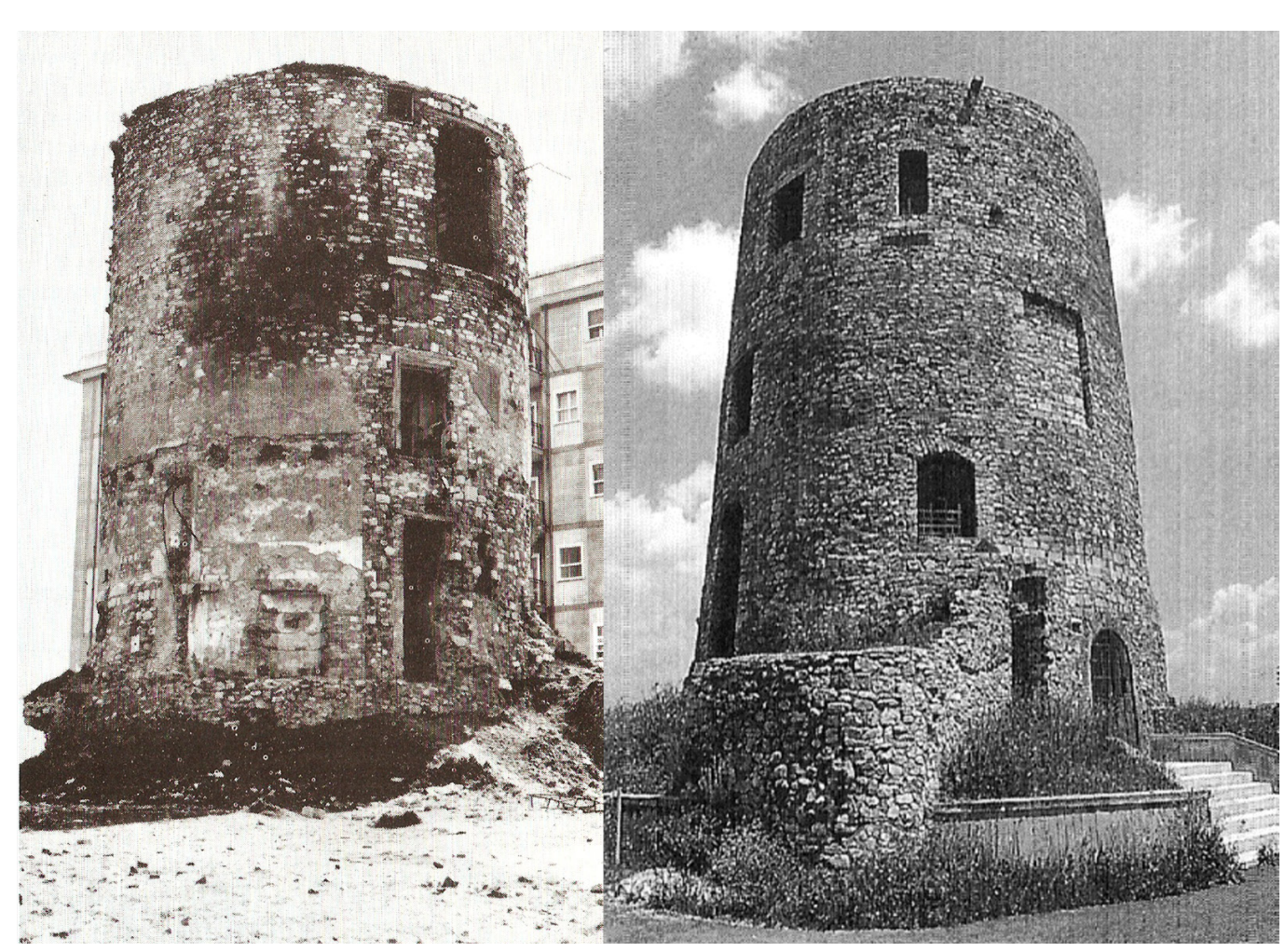


been reinterpreted only in its aesthetic component. It brings with its problems related to the engineering phases of the intervention, or structural modernization and energy improvement, which would make the housing system existing several decades ago.

This approach to recovering the existing building heritage is an alternative to 'demolition and reconstruction' and therefore becomes an opportunity to use currently available funds such as 'sismabonus', the 'ecobonus' and the 'facade bonus'.

The experience of architectural retrofitting as an application of synthesis between the knowledge and the project, through the re-design of the existing building, can trigger a virtuous process for the improvement of the quality of living.

The urban regeneration of an important fragment of the city considers its context and the elements that make it up, perceiving it as a living multicellular body that is able to metabolize the most correct choices by activating positive processes of sustainability.

We identify in the retrofit a compositive device that combines technical and technological solutions with the formal and morphological aspects of the building. Through the operations and instruments belonging to the matter of drawing and composition, such as the subtraction and addition of volumes and shapes, it is possible to define a project that belongs to the urban scale.

The addition of volumes in the facade allowed an advancement of the fronts with the gallery below. The redefinition of the facades, with a play of volumes and materials creates on each floor loggias and terraces with a flexible conformation. These offer residents the possibility to improve the internal spatial distribution of their accommodation and to have a view of the city's Urban Park.

A particular attention is placed in redesigning the cover, designed with a rearrangement of the top floor and emphasizing the overhanging flat roof element. The complex is thus reduced in height and is able to dialogue better with the Park and the Tower.
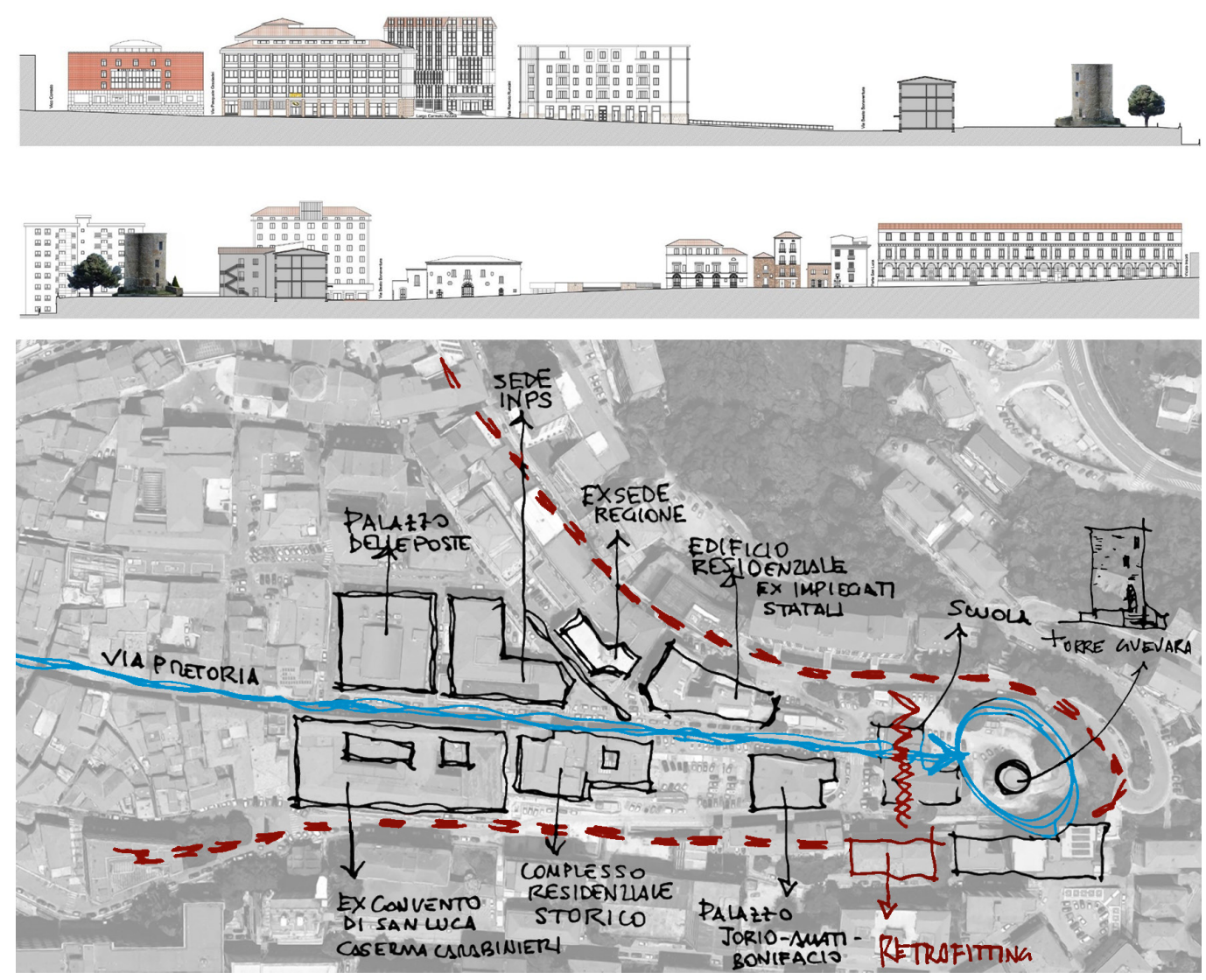

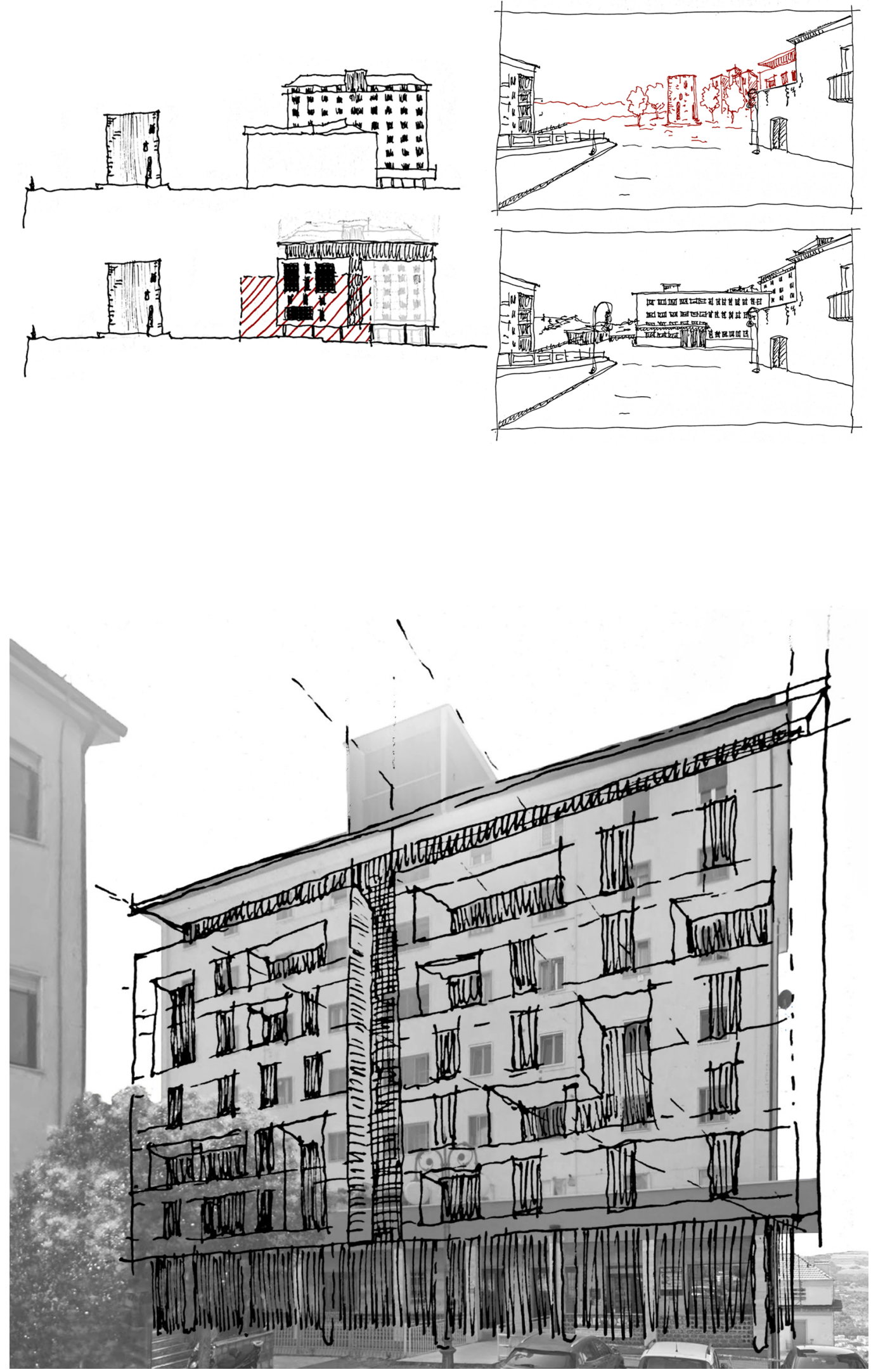
Fig. 9. Graphic elaboration, render, Urban Park and the experience of architectural retrofittin

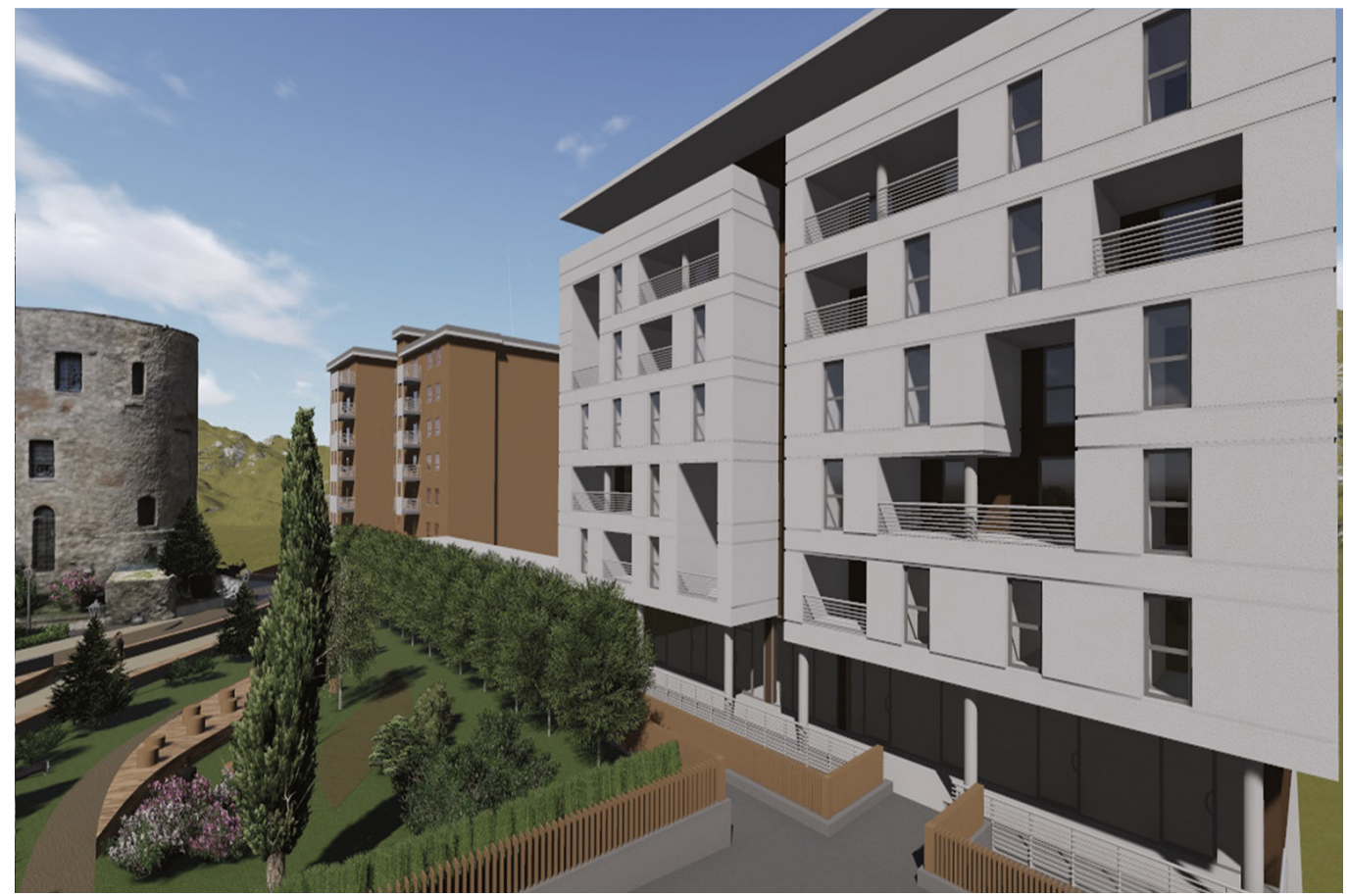

The building takes on a new language that better dialogues with the historical city, in a unicum that is composed of discontinuous elements but homogenized by reconnection to urban green. The retrofitting hypothesis adopted returns to the city, and to this portion of the historical fabric, a building with contemporary facies that interacts in a colloquiant way with other elements of the project.

In this way the reconnection took place not only on the horizontal way (via Pretoria - Torre) but also on the vertical way, where the height of the tower dialogues with the height of the built-up that surrounds it and that representing the true walls of the historic city.

The study has succeeded in realizing (ideally) the objective of giving new identity and dignity and urban quality to the area of Guevara Tower in Potenza, constantly supported by the two-way relationship between the discipline of Survey and Drawing.

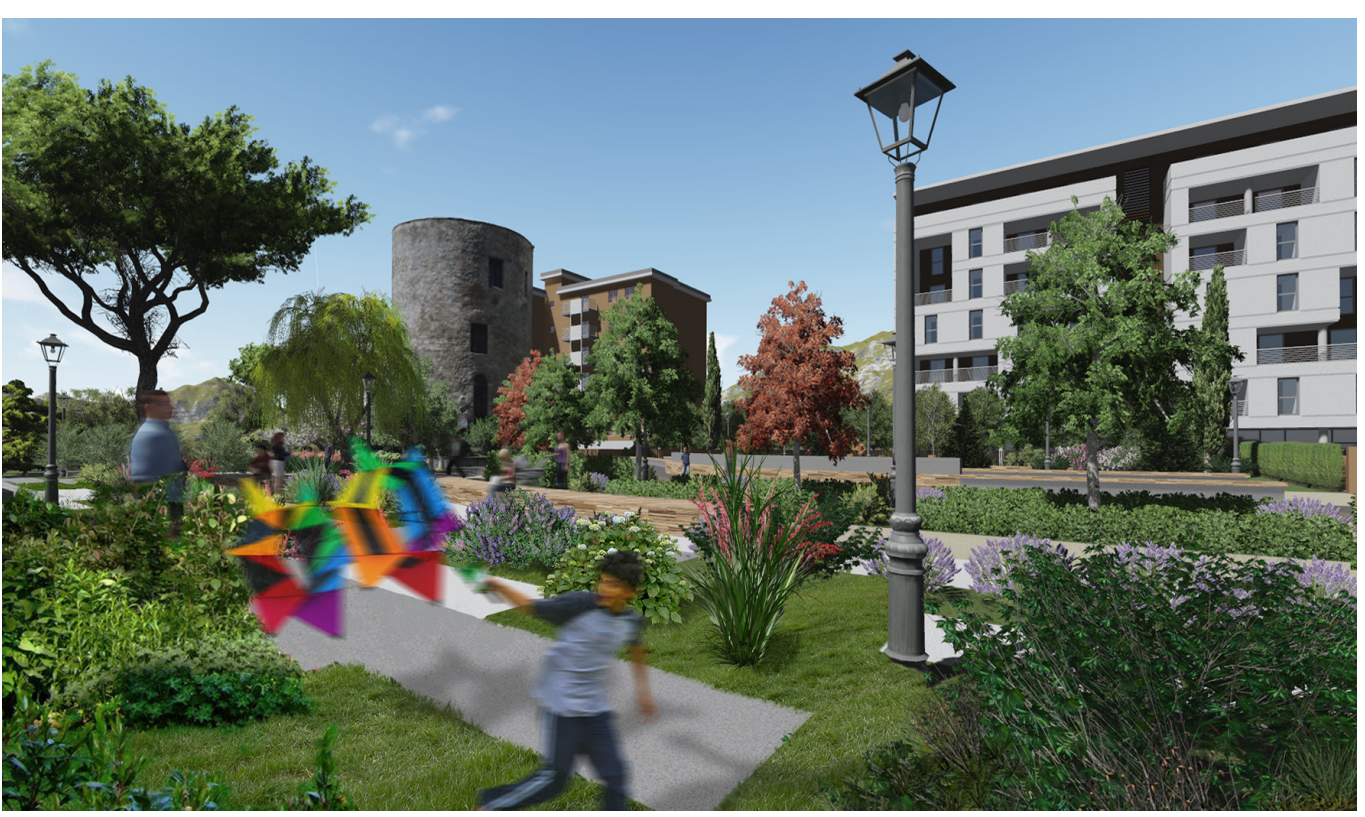




\section{Notes}

[I]This study was partially treated by Daniela Sabato in her graduation Thesis at Scuola di Ingegneria of Università degli studi della Basilicata, 20 I 8-2019 academic year, Supervisor Prof. Ing. Antonio Bixio, title 'From Survey to the recovery of the historical centers. The Urban Park of the Guevara Tower in Potenza'

\section{References}

Ascione Paola, Bellomo Mariangela (2012). Retrofit per la residenza. Tecnologie per la riqualificazione del patrimonio edilizio in Campania. Napoli: Clean Edizioni.

ATER POTENZA(2006). L'esperienza dell'abitare: progetti e realizzazioni in provincia di Potenza. Melfi: Libria.

Bixio Antonio, Tolla Enza (2012). Un Laboratorio per il Rilievo. Salerno: CUES.

Bixio Antonio, Tolla Enza, Damone Giuseppe (20I5). Besides the Design: the Analysis and Documentation of the Ancient "Via Pretoria" in Potenza. The Most Significant Transformations of a Roman Road Axis in the Historic City. In Carmine Gambardella (a cura di). Heritage and Technology. Mind Knowledge Experience. Napoli: La Scuola di Pitagora, pp. 97- 105.

Borghini Andrea (1984). Potenza perché ... Potenza:Ente Provinciale per il Turismo.

Buccaro Alfredo (1997). Le città nella storia d'Italia Potenza. Bari: Laterza.

Damone Giuseppe (20/4). Studio dell'evoluzione architettonica del San Carlo tra iconografia e storiografia. In Verrastro Valeria, Castronuovo Angela (a cura di). Per ben servire l'umanità languente. Lagonegro: Zaccaria Editore pp. 88-92.

De Nucci Alberto, Tolla Enza ( 1988). Via Pretoria - Didattica della rappresentazione per la rilettura della città. Potenza:Tipografia Zafarone e Di Bello.

Giambaresio Valerio (1995). Guida all'Architettura del novecento a Potenza. Melfi: Libria.

Gregotti Vittorio (20 I4). II possibile necessario. Milano: Bompiani.

Luccioni Luigi (1983). Un Saluto da Potenza. Ercolano: La Buona Stampa.

Murgante Beniamino (2005). Le vicende urbanistiche di Potenza. Potenza: Editric Ermes.

Pacichelli Giovanni Battista ( I 702). Il regno di Napoli in prospettiva: diviso in dodeci provincie. Napoli: D.A.Parrino.

Ricciuti Michele Davide (2009). Sulle condizioni igieniche della città di Potenza: una proposta programmatica sanitaria di fine Ottocento. Lavello: Calice.

Russo Ermoli Sergio, D'Ambrosio Valeria (2012). The building retrofit challenge - Programmazione, progettazione e gestione degli interventi in Europa. Firenze: Alinea Editrice.

Secchi Bernardo (2007). Prima lezione di urbanistica. Bari: Laterza.

Sannino Anna Lisa (1990). Territorio e popolazione a Potenza nell'età moderna. Roma: Edizioni di storia e letteratura.

Verrastro Valeria, Castronuovo Angela (2014). Per ben servire l'umanità languente. Lagonegro: Zaccaria Editore.

\section{Authors}

Antonio Bixio, Università degli Studi della Basilicata, antonio.bixio@unibas.it

Giuseppe D’Angiulli, Università degli Studi della Basilicata, giuseppe.dangiulli@unibas.it

To cite this chapter: Bixio Antonio, D'Angiulli Giuseooe (2020). Dal rilievo alla pratica del retrofitting: il 'ridisegno del limite' della città storica di Potenza/From surveying to the retrofitting: the 'redesign of the limit" in the historical city of Potenza. In Arena A., Arena M., Brandolino R.G., Colistra D., Ginex G., Mediati D., Nucifora S., Raffa P. (a cura di). Connettere. Un disegno per annodare e tessere. Atti del $42^{\circ}$ Convegno Internazionale dei Docenti delle Discipline della Rappresentazione/Connecting. Drawing for weaving relationships. Proceedings of the 42th International Conference of Representation Disciplines Teachers. Milano: FrancoAngeli, pp. 915-932. 